\title{
Tree range expansion may be enhanced by escape from negative plant-soil feedbacks
}

\author{
SARAh McCARthy-NeumanN ${ }^{1}$ AND InÉs IbÁÑEZ \\ School of Natural Resources and Environment, University of Michigan, Ann Arbor, Michigan 48109 USA
}

\begin{abstract}
Many plant species are expected to shift their distributional ranges in response to global warming. As they arrive at new sites, migrant plant species may be released from their natural soil pathogens and/or deprived of key symbiotic organisms. Under such scenarios plant-soil feedbacks (PSF) will likely have an impact on plant species' ability to establish in new areas. In this study we evaluated the role that PSF may play on the migratory potential of dominant temperate tree species at the northern limit of their distributional range in the Great Lakes region of North America. To test their ability to expand their current range, we assessed seedling establishment, i.e., survival, of local and potential migrant tree species in a field transplant experiment. To test for the presence and strength of PSF, we also assessed seedling survival during establishment in a greenhouse experiment, where the potential migrant species were grown in soils collected within and beyond their distributional ranges. The combination of experiments provided us with a comprehensive understanding of the role of PSF in seedling establishment in new areas. In the field, we found that survival for most migrant species was similar to those of the local community, ensuring that these species could establish in areas beyond their current range. In the greenhouse, we found that the majority of species experienced strong negative conspecific feedbacks mediated by soil biota, but these responses occurred for most species only in low light conditions. Lastly, our combined results indicate that migrant tree species can colonize and may even have enhanced short-term recruitment beyond their ranges due to a lack of conspecific adults (and the resulting negative PSF from these adults).
\end{abstract}

Key words: Acer rubrum; Acer saccharum; Carya glabra; climate change; hierarchical Bayes; light availability; Liriodendron tulipifera; Lower Peninsula, Michigan, USA; Prunus serotina; Quercus rubra; Quercus velutina; Robinia pseudoacacia.

\section{INTRODUCTION}

Many species are predicted to shift their distributions in response to current trends in climate (e.g., Parmesan et al. 1999, Walker et al. 2002). A suitable regeneration niche will be required to ensure range expansion by species tracking global warming (Ibáñez et al. 2006). A niche determined not only by climate, but also by all the abiotic and biotic conditions (e.g., soil nutrients, photoperiod, interactions with competitors, herbivores, predators, symbionts, and pathogens) that affect recruitment of new individuals and characterize a particular site (Ibáñez et al. 2008, 2009). In order to determine future distributions, we will need species-specific information on species' performance not only with respect to the changing climate, but also with respect to the new environment as a whole (i.e., the suite of biotic and abiotic factors that characterize a site).

In particular, interactions between trophic levels such as plant-soil feedbacks (PSF) may have a large effect on seedling establishment of migrant plant species and

Manuscript received 20 December 2011; revised 21 June 2012; accepted 27 June 2012. Corresponding Editor: P. M. Kotanen.

${ }^{1}$ E-mail: sneumann@msu.edu ultimately on their new distributions. These feedbacks occur through interactions between plants and the soil in which they grow, and can cause changes to soil conditions (biotic, physical, and/or chemical) that affect plant performance (Bever 1994, Ehrenfeld et al. 2005). Plant-soil feedbacks may result in a wide range of effects, including changing population abundance (Bever et al. 1997), restricting establishment for species into certain habitats (Augspurger and Kelly 1984, O'HanlonManners and Kotanen 2004), altering successional trajectories (Kardol et al. 2007), maintaining species diversity (Mangan et al. 2010, McCarthy-Neumann and Kobe 2010a, Kulmatiski et al. 2011), shifting species distributions (Reinhart and Callaway 2006, van Grunsven et al. 2010), and altering ecosystem services (Schnitzer et al. 2011). The direction of the feedback depends on the balance between positive effects of mycorrhizal fungi, $\mathrm{N}$-fixing bacteria, and other beneficial bacteria, and negative effects of pathogens, parasites, and herbivores (Klironomos 2002, Callaway et al. 2011). Adding to this complexity is the presence of abiotic mediated PSF created by the production of allelochemicals (Stinson et al. 2006), alterations to soil physical properties (Rillig et al. 2002), and changes in nutrient availability (Finzi et al. 1998a, b). 
As seedling establishment constitutes a major demographic bottleneck for plant populations (Gurevitch et al. 2002), a species' ability to colonize a new site will depend not only on seed dispersal, but also on other factors during this vulnerable stage of recruitment. In particular, plant-soil feedbacks are likely to be one of the "important filters" (i.e., the multitude of factors influencing performance; Harper 1977) that determine recruitment patterns. Thus, focusing on PSF at the seedling stage will be critical for assessing forest dynamics in general and short-term tree species range expansion in particular.

Specifically, PSF's potential effects on species distribution patterns and abundances in a warmer world have not been thoroughly studied (but see Engelkes et al. 2008, van Grunsven et al. 2010). The impact of biotic PSF on migrant plant species ability to expand their range might be influenced by the migration ability of microorganisms comprising the soil community in their local range (e.g., most fungal soil pathogens disperse primarily through spore hydrochory and hyphal growth; Agrios 1997), and the host specificity of these organisms (Konno et al. 2011). If migrant species respond to release from enemies (Reinhart et al. 2003), but continue to interact with mycorrhizae (Callaway et al. 2011) as has shown to be the case with invasive species, we may expect a greater dominance of migrant relative to local species in the new habitat. However, establishment of migrant species may be impeded if both migrant and local species are responding to generalist pathogens, as these species may face both continued disease pressure and stress of establishing in these new habitats (which may have different resource levels and species assemblages than migrant species experienced in their old habitats).

To investigate the role of PSF in determining tree range expansion, we followed an approach in which a largescale transplant field experiment in the Great Lakes region of North America and a greenhouse experiment were carried out simultaneously. The Great Lakes region is an area of particular interest in climate change research because it is where many temperate deciduous tree species reach their northern distributional limit due to short growing seasons (Barnes and Wagner 2004; Table 1, Fig. 1 ), and is therefore an area where we expect to first observe the expansion of their distributional ranges. The field transplant experiment tested the effects of the new range on recruitment of migrant tree species with respect to the local community and provided us with realistic survival rates among the species. We also conducted a greenhouse experiment to test actual mechanisms underpinning survival patterns in the field, specifically: (1) whether PSF mediated by soil biota and/or soil abiotic factors are important in survival for our study species, and (2) whether PSF facilitate or impede successful establishment of migrant species in regions beyond their ranges. Answers to these questions allowed us to evaluate the role that PSF, both biotic and abiotic, may play on tree species range expansion.

\section{Methods \\ Field transplant experimental design}

To test seedling survival beyond their distributional range and across a wide range of resources (moisture, soil fertility, and light), we conducted a seedling transplant experiment with local and potential migrant tree species at two latitudes, within and beyond the migrants' northern range, in Michigan Lower Peninsula (Table 1, Fig. 1). Our primary goal with this experiment was to estimate in situ rates of seedling survival at these two latitudes that could then be compared among local and potential migrant species (Table 2).

Sites.-The field experiment took place during the summers of 2009 and 2010. The northernmost sites were located at the University of Michigan Biological Station. These sites, referred to from now on as northern sites or soils, represented a region into which all the selected migrant species have been predicted to move into under most climate scenarios (Prasad et al. 2007). The southernmost sites were located at the University of Michigan Edwin S. George Reserve and Radrick Forest. These forests are located in southeastern Michigan and currently contain all the selected species (Table 1, Fig. 1), and in the remainder of the study will be referred to as southern sites or soils. To sample the environmental gradients and soil communities in the area, we selected stands within the major vegetation types of the area (Table 1, Fig. 1), and in each stand we set up plots in different habitats (canopy gap vs. forest understory), which are a proxy for different light conditions.

Species.-Eighteen temperate tree species were used in the field experiment (Table 2). Species were selected based on their distributional ranges and their predicted distributional shifts (Prasad et al. 2007). We classified all species as "local," currently growing in the area, or "migrant," species predicted to move into the area. These species represent a broad range in seed sizes, shade tolerance classifications, and mycorrhizal associations (Table 2). Whereas local seed sources were used for local species, seeds were collected from locations in the northern limit of their ranges for migrants (Appendix A). Additionally, seeds were collected from southern and northern populations for some species with distributional ranges extending throughout the Great Lakes region, and were analyzed independently as if they were different species (Appendix A). Seeds that could not be collected from local forests were purchased from Sheffields Seed (Locke, New York, USA). All seeds were surface sterilized $(0.6 \% \mathrm{NaOCl}$ solution $)$ prior to stratification and again prior to germinating in greenhouse potting soil (Metro-Mix 380; Sun Gro Horticulture Canada, Vancouver, British Columbia, Canada).

Experimental design.-At each latitudinal site, we selected four vegetation stands. In each stand, we set up four replicate plots measuring $4 \times 5 \mathrm{~m}$; two plots under forest canopy and two plots under natural canopy gaps. 
TABLE 1. Locations and site description for the field transplant experiment and soil collection sites for the greenhouse experiment in Michigan's Lower Peninsula, USA.

\begin{tabular}{lll}
\hline \hline \multicolumn{1}{c}{ Site description } & \multicolumn{1}{c}{ North $45^{\circ} 36^{\prime} \mathrm{N}-84^{\circ} 41^{\prime} \mathrm{W}$} & \multicolumn{1}{c}{ South $42^{\circ} 28^{\prime} \mathrm{N}-84^{\circ} 00^{\prime} \mathrm{W}$} \\
\hline $\begin{array}{l}\text { Average extreme minimum } \\
\text { temperature }\end{array}$ & $-28^{\circ} \mathrm{C}$ & $-22^{\circ} \mathrm{C}$ \\
$\begin{array}{l}\text { Geology } \\
\text { Growing season }\end{array}$ & moraine ridges and poorly drained outwash & end-moraine ridges and ground moraine \\
Soil textures & 108 days & 158 days \\
Major soil orders & gravelly sandy, loamy & loamy and clayey \\
Dominant canopy species & Spodosols, Entisols & Alfisols \\
Stand 1 & Fagus grandifolia and Acer saccharum & Quercus alba and Quercus velutina \\
Stand 2 & Pinus strobus and Populus grandidentata & Quercus velutina and Carya glabra \\
Stand 3 & Abies balsamea and Thuja occidentalis & Acer saccharum and Quercus rubra \\
Stand 4 & Populus grandidentata & \\
\hline
\end{tabular}

Notes: North and south refer to the location of the transplant sites and also to where soils were collected for the greenhouse experiment. Elevation along the sites ranges from 180 to $525 \mathrm{~m}$. In each of the stands four plots (two in canopy and two in gap habitats) were established (except for stands 2 and 3 in the south, with six plots each) for the transplant experiment. Stand 1 in the north and an additional stand not used in the field experiment (located at University of Michigan's Horner Woods in Ann Arbor, Michigan) were used to collect soil for the greenhouse experiment.

We had a total of 16 plots (2 latitudes $\times 3-4$ stands $\times 2$ canopy levels $\times 2-4$ plots), and in each of the experimental plots, we transplanted 5-20 seedlings of each species (number of seedlings varied among species depending on germination success) that were $\sim 4$ weeks in age. Seedlings were planted $25 \mathrm{~cm}$ apart. Additionally, seedlings in one of the replicated plots were treated immediately after planting with a mixture of fungicides (Subdue Maxx and Medallion; Syngenta, Basel, Switzerland); seedlings in the control plots were watered with the same volume of water $(100 \mathrm{~mL})$. However, there was no evidence that fungicide treatment had any effect on seedling survival (data not shown), and the fungicide factor was excluded from any further comparisons in the model. A total of 7683 seedlings in 2009 and 6672 seedlings in 2010 were planted (Table 2).

Environmental measurements.-We combined temporally extensive (hourly) environmental data taken at one point for each stand with spatially extensive environmental data taken at each of the four plots per stand to estimate cumulative light (PAR, phototosynthetically active radiation) and average soil moisture at each plot for every two-week period during the 2009 and 2010 growing seasons (see Appendix B for more detailed methods). Soil resources (inorganic $\mathrm{N}, \mathrm{NH}_{4}^{+}, \mathrm{NO}_{3}^{-}$, total soil $\mathrm{C}$ and $\mathrm{N}, \mathrm{Mg}^{2+}, \mathrm{Ca}^{2+}, \mathrm{K}^{+}$and $\mathrm{PO}_{4}{ }^{-}$, and soil $\mathrm{pH}$ ) were also measured for each plot (see Appendix $\mathrm{C}$ for methods and results).

Seedling measurements.-Height was measured before planting to account for any differences in survival due to initial seedling size. Survivorship was recorded every two weeks after transplant into the field for 10 weeks. The first census was used to identify seedlings that died due to transplant shock during the first two weeks and their data were not used in the analyses.

\section{Greenhouse experimental design}

To investigate the role of plant-soil feedbacks in determining seedling establishment in new areas, we conducted a greenhouse experiment with eight tree species common to the region (all southern seed sources; Table 2). We collected soils near adults of each species in a southern site, and for three species soils were also collected in a northern site (Table 1, Fig. 1). We grew seedlings in either non-sterile or sterilized field soils across a range of irradiance levels and assessed survival. Seed collection and preparation followed the same protocol as described for the field experiment.

Soil sources.-We did not follow the common approach of setting up multistage feedback experiments (e.g., Bever et al. 2010). Instead we used soil cultured in situ by mature trees for several reasons: (1) to minimize changes in soil biota composition and diversity that our experimental seedlings initially experience (Sykorova et al. 2007); (2) because individual mature trees (unlike grasses which are the focal species in most PSF experiments) have an easily discernible area where soil

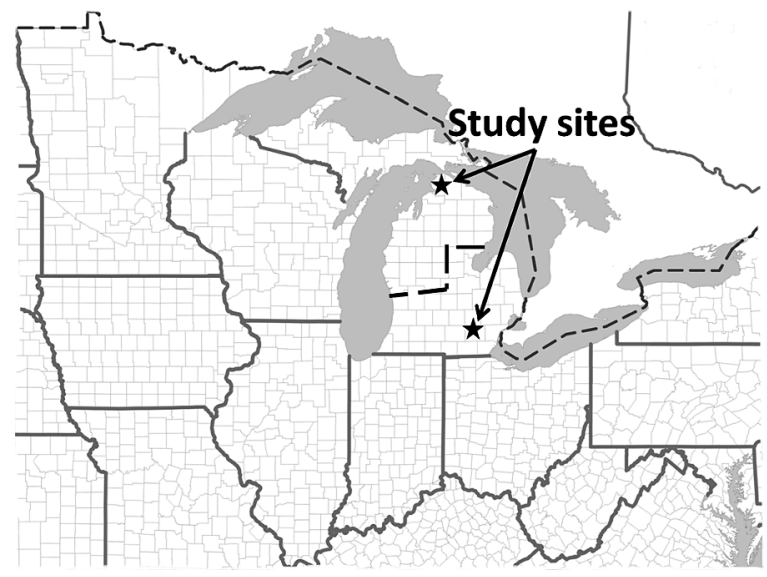

FIG. 1. Locations for the field transplant experiment and soil collection sites for the greenhouse experiment in Michigan's Lower Peninsula, USA. The black dashed line indicates the northern distributional limit for the studied potential migrant tree species in Michigan (Little 1971). 
TABLE 2. Study species, local and potential migrants, their geographical source, summer planted, shade tolerance status, symbiotic associations, and average seed mass.

\begin{tabular}{|c|c|c|c|c|c|c|c|}
\hline \multirow[b]{3}{*}{ Species name (code) } & \multicolumn{4}{|c|}{$\begin{array}{c}\text { Field transplant sites, } \\
\text { northern }(\mathrm{N}) \text { and southern }(\mathrm{S})\end{array}$} & \multirow{3}{*}{$\begin{array}{l}\text { Shade } \\
\text { tolerance }\end{array}$} & \multirow{3}{*}{$\begin{array}{l}\text { Mycorrhizal } \\
\text { association }\end{array}$} & \multirow{3}{*}{$\begin{array}{c}\text { Seed } \\
\text { mass }(\mathrm{mg})\end{array}$} \\
\hline & \multicolumn{2}{|c|}{ Geographic source } & \multicolumn{2}{|c|}{ Summer planted } & & & \\
\hline & 2009 & 2010 & 2009 & 2010 & & & \\
\hline \multicolumn{8}{|l|}{ Local species } \\
\hline Acer rubrum (Acru) & $\mathrm{N}$ & $\mathrm{N}$ and $\mathrm{S}$ & $\mathrm{N}$ & $\mathrm{S}$ & tolerant & AMF & 19.6 \\
\hline Acer saccharum (Acsa) & $\mathrm{N}$ and $\mathrm{S}$ & S & $\mathrm{S}$ & $\mathrm{S}$ & very tolerant & AMF & 64.9 \\
\hline Betula papyrifera (Вера) & $\mathrm{N}$ and $\mathrm{S}$ & & $\mathrm{N}$ and $\mathrm{S}$ & & intolerant & $\mathrm{AMF}$ and $\mathrm{EMF}$ & 0.3 \\
\hline Pinus banksiana (Piba) & $\mathrm{N}$ & & $\mathrm{N}$ & & intolerant & $\mathrm{AMF}$ and $\mathrm{EMF}$ & 3.4 \\
\hline Pinus strobus (Pist) & $\mathrm{N}$ & & $\mathrm{N}$ & & intermediate & $\mathrm{AMF}$ and $\mathrm{EMF}$ & 17.1 \\
\hline Prunus serotina (Prse) & & & & $\mathrm{N}$ and $\mathrm{S}$ & intolerant & AMF & 94.3 \\
\hline Quercus rubra (Quru) & $\mathrm{N}$ and $\mathrm{S}$ & $\mathrm{N}$ and $\mathrm{S}$ & $\mathrm{N}$ and $\mathrm{S}$ & $\mathrm{N}$ and $\mathrm{S}$ & intermediate & $\mathrm{AMF}$ and $\mathrm{EMF}$ & 4127.0 \\
\hline $\begin{array}{l}\text { Tsuga canadensis } \\
\text { (Tsca) }\end{array}$ & & & & $\mathrm{N}$ and $\mathrm{S}$ & very tolerant & $\mathrm{AMF}$ and $\mathrm{EMF}$ & 10.0 \\
\hline \multicolumn{8}{|l|}{ Migrant species } \\
\hline Carya glabra (Cagl) & $\mathrm{S}$ & $\mathrm{S}$ & $\mathrm{S}$ & $\mathrm{S}$ & intermediate & AMF and EMF & 2272.0 \\
\hline Carya ovata (Caov) & $\mathrm{S}$ & $\mathrm{S}$ & $\mathrm{S}$ & $\mathrm{S}$ & intermediate & $\mathrm{AMF}$ and EMF & 4545.0 \\
\hline $\begin{array}{l}\text { †Celastrus orbiculatus } \\
\quad \text { (Ceor) }\end{array}$ & & & & $\mathrm{S}$ & tolerant & $\mathrm{AMF}$ & 17.5 \\
\hline $\begin{array}{l}\dagger \text { Elaeagnus umbellata } \\
\text { (Elum) }\end{array}$ & & & & $\mathrm{S}$ & intolerant & $\mathrm{AMF}, \mathrm{EMF}$, and NFB & 16.1 \\
\hline $\begin{array}{l}\text { Liquidambar styraciflua } \\
\text { (List) }\end{array}$ & & $\mathrm{S}$ & & $\mathrm{S}$ & intolerant & $\mathrm{AMF}$ & 6.1 \\
\hline $\begin{array}{l}\text { Liriodendron tulipifera } \\
\quad(\text { Litu) }\end{array}$ & & $\mathrm{S}$ & & S & intolerant & $\mathrm{AMF}$ & 40.0 \\
\hline Nyssa sylvatica (Nysy) & $\mathrm{S}$ & $\mathrm{S}$ & & $\mathrm{S}$ & intolerant & AMF & 153.8 \\
\hline Quercus alba (Qual) & & $\mathrm{S}$ & & $\mathrm{S}$ & intolerant & $\mathrm{AMF}$ and $\mathrm{EMF}$ & 6676.0 \\
\hline $\begin{array}{l}\$ \text { Quercus velutina } \\
\text { (Quve) }\end{array}$ & $\mathrm{S}_{\mathrm{U}}$ & $\mathrm{S}_{\mathrm{U}}$ and $\mathrm{S}_{\mathrm{L}}$ & $\mathrm{S}_{\mathrm{U}}$ & $\mathrm{S}_{\mathrm{U}}$ and $\mathrm{S}_{\mathrm{L}}$ & intolerant & $\mathrm{AMF}$ and EMF & 1570.0 \\
\hline $\begin{array}{l}\dagger \text { Robinia pseudoacacia } \\
\text { (Rops) }\end{array}$ & & $\mathrm{S}$ & & & intolerant & $\mathrm{AMF}, \mathrm{EMF}$, and NFB & 18.9 \\
\hline
\end{tabular}

Notes: Species in bold were also used in the greenhouse experiment. Abbreviations are: N, northern sources, $\mathrm{S}$, southern sources; AMF, arbuscular mycorrhizal fungi; EMF, ectomycorrhizal fungi; and NFB, nitrogen-fixing bacteria. Northern and southern sites refer to the location of the transplant sites. Shade tolerance status and seed mass data are from Burns and Honkala (1990).

$\uparrow$ Species considered invasive in Michigan.

$\$$ Seeds for $Q$. velutina were collected from two latitudes within the southern region: $\mathrm{S}_{\mathrm{U}}$ from the upper and $\mathrm{S}_{\mathrm{L}}$ from the lower location.

interaction could be occurring and attributable to that one individual (i.e., under its crown); and (3) since trees are long-lived species, specific changes to the soil are already in place, which means that further culturing in the greenhouse does not necessarily change the feedback created in the field (McCarthy-Neumann and Kobe 2010b).

We collected soil from southern and northern forest communities for three of the species (A. rubrum, $A$. saccharum, and $Q$. rubra). In addition, we collected soils at the southern location from under the canopy of the four southern species (C. glabra, L. tulipifera, $Q$. velutina, and $R$. pseudoacacia) and of Prunus serotina. Although considered local at our northern latitude, this last species was not present as an adult in the northern area. We removed soil samples $(30 \mathrm{~cm}$ diameter $\times 15 \mathrm{~cm}$ depth) from four points within $1 \mathrm{~m}$ from the bole of four mature adults. To minimize potential for multispecies culturing of soil, we took soil under trees that were at least two crown diameters away from adults of other study species. Soil was collected in late October through early November 2009 when microorganisms were likely to be present as spores, enabling higher microbe survival during transport and cold storage (Reinhart et al. 2005).

Each soil source (species of adult tree culturing the soil) at a particular site was aggregated into one bulk sample and prepared for use in the experiment by dicing roots and sifting soil through a $1-\mathrm{cm}$ mesh sieve. Each soil source was split into two fractions with threefourths of the soil sterilized by gamma irradiation $(\sim 30$ KGray; Sterigenics International, Schaumburg, Illinois, USA). Non-sterilized field soil was stored at $4^{\circ} \mathrm{C}$ for two months; soil destined for irradiation was stored for one month at $4^{\circ} \mathrm{C}$ and then an additional month at ambient greenhouse temperatures $\left(\sim 21^{\circ} \mathrm{C}\right)$ after irradiation. To avoid cross-contamination and transfer of soil biota, all tools and surfaces coming in contact with non-sterilized soil were soaked in $10 \%$ bleach solution or surface sprayed with $70 \%$ ETOH solution. To test for chemical differences among soils, we measured a variety of nutrients in two replicates for each soil source and treatment as well as the sterile commercial peat soil at the onset of the experiment (Appendix C).

Planting methods and data collection.-Seeds with newly emerged radicles were weighed and then planted 
into $6.4 \mathrm{~cm}$ diameter $\times 25 \mathrm{~cm}$ depth pots. Seedlings were grown in: (1) the "non-sterile treatment," a 1:1:2 mixture of non-sterile field soil, sterile field soil, and sterile peat soil (Fafard Mix number 2; Conrad Fafard, Agawam, Massachusetts, USA); (2) a "sterile treatment," a 1:1 mixture of sterile field soil and sterile peat soil; and (3) a control with seedlings planted in $100 \%$ sterile peat soil. Individual pots were set up on 12 benches where all combinations were represented.

To mimic the variability of the light environment in the field, seedlings were grown at three light levels (comparable to $1.3 \%, 3.8 \%$, and $29 \%$ full sun, respectively; see Appendix B). Seedlings were watered ( $\sim 50$ $\mathrm{mL}$ of deionized water, DI) by hand every three days for 10 weeks. To determine if irradiance influenced water availability, we measured percentage soil moisture at each bench (see Appendix B). Due to low seed germination, some species were not grown in all soil sources from the southern range (see Appendix D). Emergence and survival were recorded once a week. We assigned date of death as the first census with total leaf and/or stem tissue necrosis.

\section{Analytical approach}

We used a counting process in a Cox survival model (Andersen and Gill 1982) to include as many factors as possible that could have influenced seedling survival. This model allows for ample flexibility in the estimation of the hazard and the frailty (Fleming and Harrington 1991, Andersen et al. 1993). Here the data for each seedling $i$ and each time $t, N_{i t}$, are coded as 0 until the seedling is found dead, then $N_{i t}=1$, which would be the last time period accounted for. A count process models the number of events (failures, $N_{i t}$ ) that have occurred up to continuous time. We model the likelihood as

$$
N_{i t} \sim \operatorname{Poisson}\left(\lambda_{i t}\right)
$$

where $\lambda$ is the intensity function, that is then estimated as a function of the intrinsic rate of mortality, or hazard $h$, and the extrinsic risk of mortality, or risk $\mu$ :

$$
\lambda_{i t}=h_{t} e^{\left(\mu_{i t}\right)} .
$$

Parameters in the model were estimated at the species level following a Bayesian approach that allowed us to consider the different sources of uncertainty associated with the data and gave us flexibility when including fixed and random effects (Clark 2005, Gelman and Hill 2007). The hazard was estimated for each time step, $h_{t}$, from a gamma distribution with noninformative parameter values, $h_{t} \sim \operatorname{gamma}(0.01,0.01)$. This intrinsic mortality rate reflects the temporal variability in mortality that is not accounted for by the risk function, $\mu_{i t}$. The risk, $\mu_{i t}$, was estimated as a function of the covariates included in the analysis, $\mu_{i t}=\mathbf{X}_{i t} \mathbf{B}$. $\mathbf{X}_{i t}$ is the matrix of covariates associated with each seedling $i$ at each time $t$. $\mathbf{B}$ is the vector of fixed effect coefficients associated with each covariate. These coefficients were estimated from normal distributions with noninformative parameter values, $\quad \mathbf{B}_{k} \sim \operatorname{normal}(0,10000)$. We tried several combinations of covariates (seed or seedling size, soil moisture, light level, soil nutrients for both field and greenhouse experiment; habitat, region, and fungicide treatment for the field experiment; and soil source, region, and soil sterilization treatment for the greenhouse experiment). Random effects (e.g., year, stand, and plot for the field experiment, and bench for the greenhouse) were also included in the different models we tried. We then selected the model that best predicted the data across species based on the DIC (deviance information criterion; Spiegelhalter et al. 2000). For the final model, the covariates included in the analysis of the field data were: seedling size, soil moisture, light, habitat type (open vs. canopy), and region $\times$ fungicide treatment (north-south and fungicide-control combinations; for this covariate, we only report results for the control group as the fungicide treatment did not have an effect). For the greenhouse experiment, the covariates included were: seed mass, soil moisture, light, soil source (species), and treatment (non-sterile vs. sterile). To test the difference between habitats and regions for the field experiment and treatments and soil sources for the greenhouse experiment, we estimated the difference between associated parameters (e.g., open-canopy or sterile-non-sterile); a significant result would then have a 95\% credible interval around the posterior mean of the difference that does not include zero.

As differences in survival are ecologically more meaningful than model parameter comparisons, we obtained predicted survival from the parameter values in our field- and greenhouse-based models. Predicted survival to time $t, \hat{S}_{t}$, was estimated as part of the Markov chain Monte Carlo simulation once the parameters had converged:

$$
\hat{S}_{t}=\exp \left(-\int_{1}^{t} h\right)^{\exp \left(\mu_{t}\right)} .
$$

This procedure allowed us not only to consider the variability inherent in each parameter (their variances), but also the correlations between parameters (their covariances). Predicted survival values were used to assess whether there were differences in how species responded to habitat (canopy vs. open) and region (north vs. south) for the field experiment, and to soil source groupings (conspecific vs. pooled heterospecific groupings) and light levels (low vs. high) for the greenhouse experiment.

Models were run for each species separately in OpenBUGS 1.4 (Thomas et al. 2006); simulations (three chains) were run until convergence of the parameters was ensured $(\sim 50000$ iterations $)$ and then run for another 25000 iterations from which posterior parameter values and predicted survival were estimated. The Cox survival model analyzes risk of mortality, so we report the posterior values for the fixed effect coeffi- 
cients $\left(B_{k}\right)$ multiplied by -1 to reflect their effect on survival instead.

Determination of plant-soil feedbacks in the greenhouse experiment. - In order to test for the effect of plant-soil feedbacks, we assessed seedling survival between soil sources in non-sterile soil. Plant-soil feedbacks were deemed negative when conspecific soil was detrimental relative to heterospecific soils (individual and pooled soils) and were deemed positive when conspecific soil was beneficial relative to heterospecific soils. In order to test whether the mechanism causing the PSF was biotic or abiotic, we determined whether the PSF occurred only when comparing non-sterile soil sources (biotic agent) or in both non-sterile and sterile soils sources (abiotic agents). If the mechanisms causing the PSF were determined to be biotic, we compared survival between non-sterilized and sterilized soils to determine if the biotic agents were occurring in conspecific and/or heterospecific soil.

\section{RESULTS \\ Field survival}

Seedling hazard varied among species, but the general pattern showed peak mortality a few weeks after planting, and a decline as the season progressed (Appendix E). The effect of initial seedling size, soil moisture, and light availability also varied among species (see Appendix F for the full table of parameter values). Of 18 species planted in the field experiment, 15 species had greater survival with larger initial size, and most species experienced enhanced survival under higher soil moisture. In addition, most species had higher survival in lower light plots (PAR in understory plots = $13.9 \pm 3.7$, and in gap plots, PAR $=47.3 \pm 3.7 \mu \mathrm{mol}$ photons $\cdot \mathrm{m}^{2} \cdot \mathrm{s}$; mean $\pm \mathrm{SD}$ ).

After accounting for light and soil moisture, seven species had significantly higher survival under canopy relative to open habitats at the northern site (Fig. 2a). Overall survival of migrant species was similar to or higher than survival of all local species (Fig. 2b). For instance, in canopy plots at the northern stands seven of the southern species/populations (A. rubrum, A. saccharum, C. glabra, C. ovata, L. tulipifera, $Q$. alba, and $R$. pseudoacacia) had survival rates significantly higher than those of three of the local species/populations ( $A$. rubrum, B. papyrifera, and P. banksiana; $95 \%$ predicted survival intervals do not overlap). Southern B. papyrifera, $N$. sylvatica, and $Q$. rubra also had significantly higher survival in northern plots than northern $A$. rubrum and $B$. papyrifera. In addition, southern $C$. glabra had higher survival in the north than northern $A$. saccharum, and southern $A$. saccharum had higher survival in the north than northern $A$. saccharum and $P$. strobus. Lastly, there were no southern species whose survival was significantly lower in the northern canopy plots than any of the local species (Fig. 2b).

When just comparing canopy habitats, two of the local tree species ( $P$. banksiana and $P$. strobus) had significantly greater survival in the north than the south (Fig. 2b). Among the group of potential migrants, $L$. tulipifera and the southern populations of A. rubrum and $B$. papyrifera had greater survival in northern plots, whereas $Q$. velutina upper and lower ranges and $C$. ovata had greater survival in southern plots (Fig. 2b).

\section{PSF in the greenhouse experiment}

For small-seeded species, hazard curves show a peak in mortality around week 3-4 and in some species there were also multiple peaks of relatively higher mortality over the course of the experiment (Appendix E). Largeseeded species (C. glabra, Q. rubra, and $Q$. velutina) tended to have nearly no change until the end of the experiment, which was around the time these seedlings began to lose their cotyledon support (S. McCarthyNeumann, personal observation).

Covariates also had a varying effect on the study species (see Appendix F for the full table of parameter values). Seed mass significantly affected survival for only two species (L. tulipifera and $R$. pseudoacacia). Survival was not significantly influenced by differences in soil moisture for any species. Survival increased with light in four of the smaller seeded species (A. rubrum, $A$. saccharum, $P$. serotina, and $R$. pseudoacacia), whereas light did not affect survival of the large-seeded species (C. glabra, Q. rubra, and Q. velutina), or L. tulipifera.

Plant-soil feedbacks.-Sterilization of soil biota through gamma irradiation and efforts to minimize cross contamination appeared to have been effective. We assessed mycorrhizal fungal colonization for all harvested seedlings and found zero colonization in the sterilized field or peat soil treatments (S. McCarthy-Neumann and I. Ibáñez, unpublished manuscript). Additionally, dying seedlings in the non-sterile field soil often experienced classic damping-off symptoms.

Soil source and sterilization treatments had varying effects on seedling survival (see Appendix F for the full table of parameter values). Soil source affected survivorship in seven species when comparing non-sterile soil sources. The incidence of PSF varied depending on the region or origin and on the light treatment. When comparing southern soils, three species (P. serotina, $Q$. rubra, and $R$. pseudoacacia) experienced negative PSF, meaning that conspecific soil was detrimental relative to pooled heterospecific soils, but only in low light (Fig. 3a). Only one species experienced negative PSF at both high and low light (L. tulipifera), and one species $(Q$. velutina) experienced positive PSF, manifesting higher survival in its own soil in comparison with pooled heterospecific soils at low light. Comparisons between regions, southern conspecific soil, and northern heterospecific soils (Fig. 3b), show the same pattern except for two species: $Q$. velutina, for which southern conspecific soils did not seem to enhance survival over northern heterospecific soils, and A. rubrum, which experienced negative PSF. For the three species that we have northern soil sources, negative PSF only occurred for 

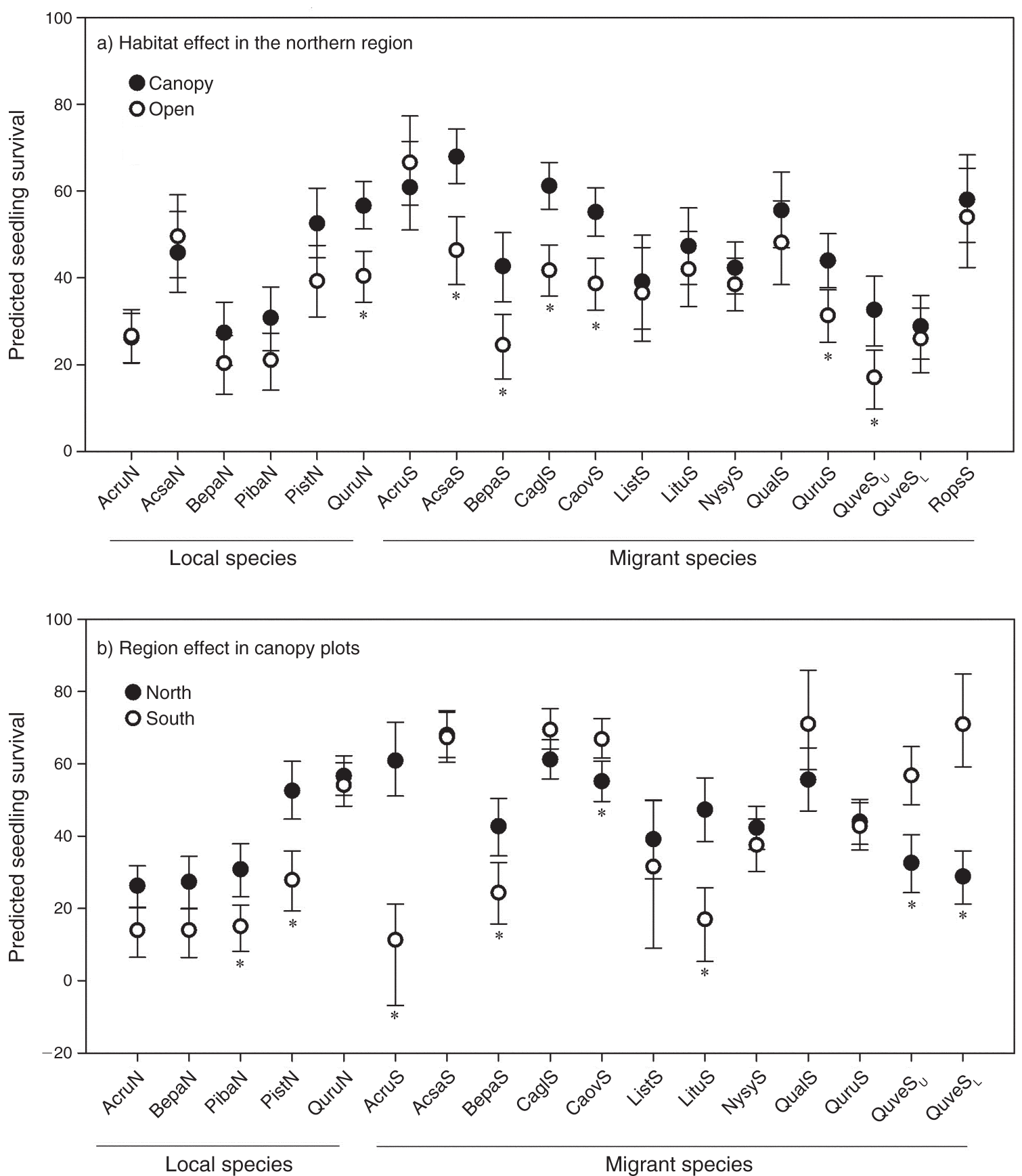

FIG. 2. Predicted seedling survival (mean and $95 \%$ prediction intervals) for each field study species after 10 weeks based on model parameters: (a) in canopy vs. open habits in northern sites, and (b) in north vs. south regions in canopy habitats. Intervals that do not overlap indicate statistically significant differences between habits or regions and are indicated by an asterisk. For species code key see Table 2; seed source abbreviations are N, northern, and S, southern.

$* P>0.05$.

A. saccharum seedlings at low light (Fig. 3c). These PSF interactions were species-specific (e.g., the heterospecific species culturing the soil mattered) because all species (except Q. rubra) that had an overall PSF between conspecific and pooled heterospecific soils did not have significant differences with each individual heterospecific soil (Table 3, Fig. 4).
Besides the strong influence that conspecific soils had on survival, there were two other important soil source trends. Survival was greatest for five out of eight species in A. saccharum soil (Appendix F: Fig. F1); for most species this was due to favorable abiotic effects and occurred regardless of sterilization treatments (Table 3; Appendix F: Fig. F1). In general, seedlings also had 
a) PSFs in the south

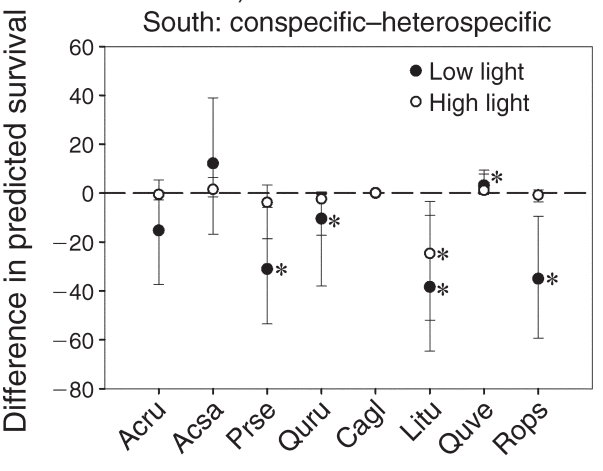

Local species Migrant species b) PSFs between regions Conspecific south-heterospecific north

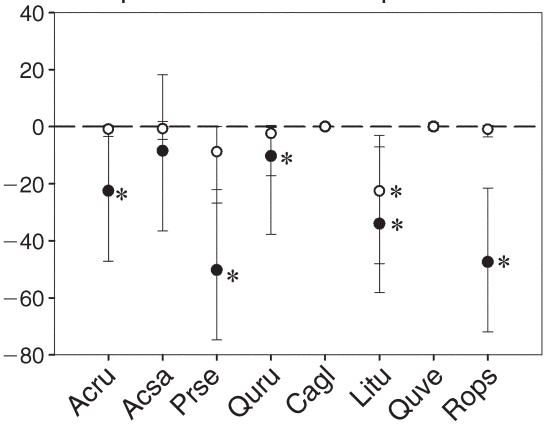

Local species Migrant species c) PSFs in the north North: conspecific-heterospecific

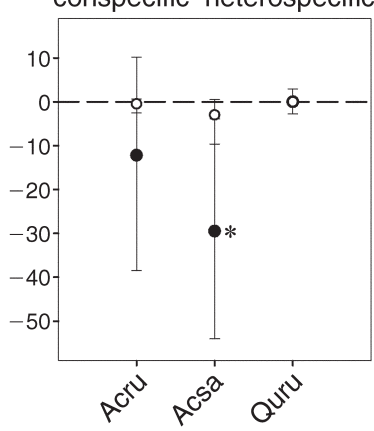

FIG. 3. Plant-soil feedback (PSF) effect at both low and high light (predicted survival in conspecific-pooled heterospecific nonsterile soil sources; mean and 95\% CI): (a) in the southern range, (b) during range expansion, and (c) in the northern range. Confidence intervals that do not overlap indicate statistically significant differences in predicted survival between soil source treatments, as indicated by asterisks. For species code key see Table 2.

$* P>0.05$

better survival in northern than southern Q. rubra soil, which may have been primarily driven by a release from soil pathogens associated with the southern-collected $Q$. rubra soil (Table 3; Appendix F: Fig. F1).

Biotic and abiotic effects of PSF.-When comparing sterile vs. non-sterile soils to discriminate between the biotic vs. abiotic nature of the PSF, we found that most PSF were caused by the negative effects of soil biota in conspecific soil (Table 3). Q. velutina, however, experienced positive PSF between conspecific and some heterospecific soils, which was due to the negative effects of soil biota in the heterospecific soils. There were also three instances (with A. rubrum and Q. rubra seedlings) in which a negative PSF between a conspecific and heterospecific soil was due to both the negative effects of soil biota in the conspecific soil and the positive effects of soil biota in the heterospecific soil. In addition, for $R$. pseudoacacia, we could only determine that the negative PSF between conspecific and northern A. saccharum soils was mediated by soil organisms, but we could not isolate whether the effects were in the conspecific or heterospecific soils. There were very few instances where the PSF was mediated by soil abiotic properties (Table 3). Among the southern soils, only $R$. pseudoacacia experienced negative abiotic PSF in comparison with $A$. rubrum and A. saccharum soils. Negative abiotic PSF also occurred when comparing southern conspecific soil with northern A. saccharum

TABLE 3. Summary of the results indicating the occurrence of PSF (plant-soil feedbacks, positive or negative) and the mechanisms causing them, biotic or abiotic.

\begin{tabular}{|c|c|c|c|c|c|c|c|c|c|c|c|}
\hline \multirow[b]{2}{*}{ Species $\dagger$} & \multicolumn{8}{|c|}{ Southern soils } & \multicolumn{3}{|c|}{ Northern soils } \\
\hline & Acru & Acsa & Cagl & Litu & Prse & Quru & Quve & Rops & Acru & Acsa & Quru \\
\hline Acru & own soil & PSF- & & NA & & & & PSF- & & & \\
\hline Acsa & & $\begin{array}{l}\text { Biotic- } \\
\text { own soil }\end{array}$ & NA & NA & NA & NA & NA & $\begin{array}{c}\text { Biotic }+,- \\
\text { NA }\end{array}$ & & & \\
\hline Cagl & & & own soil & NA & NA & & NA & NA & & & \\
\hline Litu & & $\begin{array}{l}\text { PSF- } \\
\text { Biotic- }\end{array}$ & NA & own soil & NA & & NA & NA & & & $\begin{array}{l}\text { PSF-- } \\
\text { Biotic- }\end{array}$ \\
\hline Prse & & $\begin{array}{l}\text { PSF- } \\
\text { Biotic- }\end{array}$ & NA & NA & own soil & & $\begin{array}{c}\text { PSF-- } \\
\text { Biotic- }\end{array}$ & & & $\begin{array}{l}\text { PSF- } \\
\text { Abiotic }\end{array}$ & $\begin{array}{l}\text { PSF-- } \\
\text { Biotic- }\end{array}$ \\
\hline Quru & PSF- & PSF- & $\begin{array}{c}\text { PSF- } \\
\text { Biotic- }\end{array}$ & NA & PSF- & own soil & PSF- & PSF- & PSF- & PSF- & PSF- \\
\hline Quve & & $\begin{array}{l}\text { PSF+ } \\
\text { Biotic- }\end{array}$ & & NA & $\begin{array}{l}\text { B1otic- } \\
\text { PSF+ } \\
\text { Biotic- }\end{array}$ & $\begin{array}{c}\text { PSF+ } \\
\text { Biotic- }\end{array}$ & own soil & Biot & Iotic- & B1otic- & Biotic \\
\hline Rops & $\begin{array}{l}\text { PSF- } \\
\text { Abiotic }\end{array}$ & $\begin{array}{l}\text { PSF- } \\
\text { Abiotic }\end{array}$ & NA & NA & NA & & & own soil & $\begin{array}{l}\text { PSF- } \\
\text { Abiotic }\end{array}$ & $\begin{array}{l}\text { PSF- } \\
\text { Biotict }\end{array}$ & $\begin{array}{l}\text { PSF- } \\
\text { Abiotic }\end{array}$ \\
\hline
\end{tabular}

Notes: Following Appendix F: Table F2 and Fig. F1, only statistically significant results indicated by nonoverlapping $95 \%$ CI are presented. Empty cells indicate that no significant PSF occurred for seedlings of this species that were planted in that soil. NA, not applicable; seedlings of this species were not planted in that soil.

$\uparrow$ For species code key, see Table 2.

W We were not able to determine the type of biotic effect. 


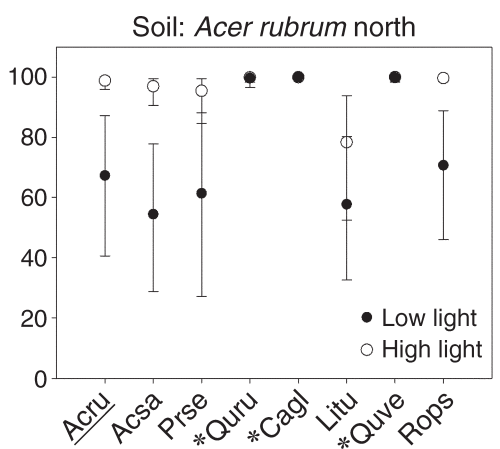

Soil: Acer saccharum north

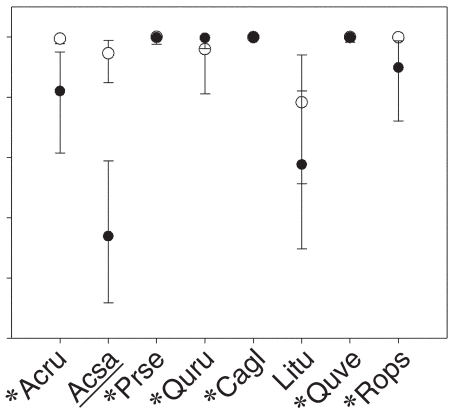

Soil: Acer saccharum south

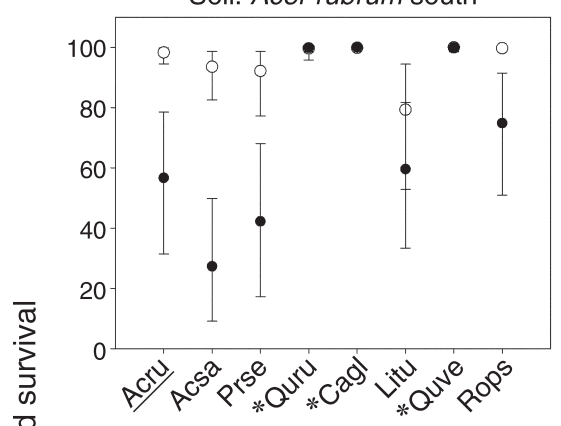

Soil: Carya glabra south

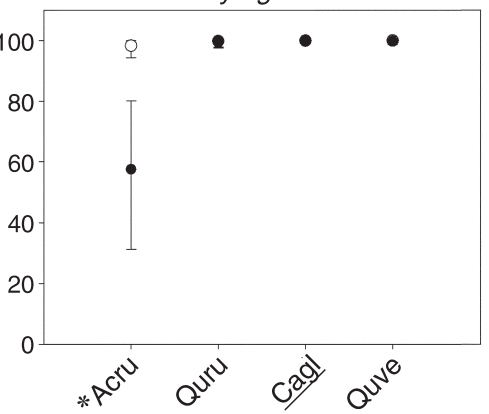

Soil: Quercus velutina south

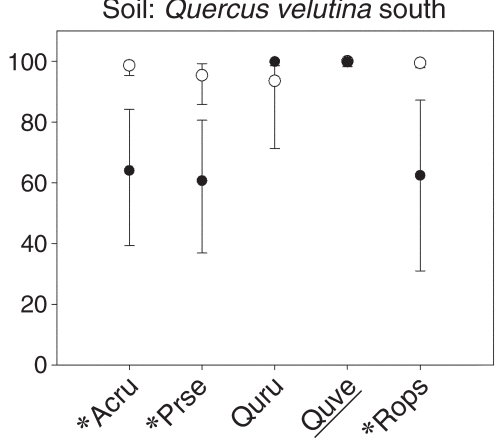

Species planted

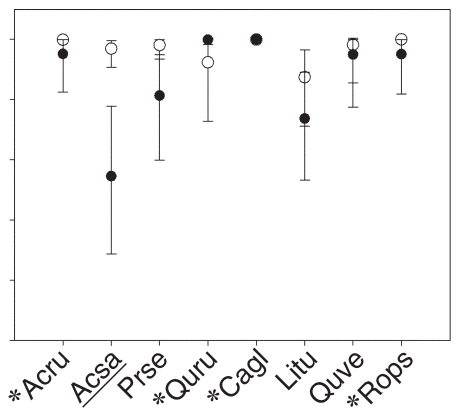

Soil: Prunus serotina south

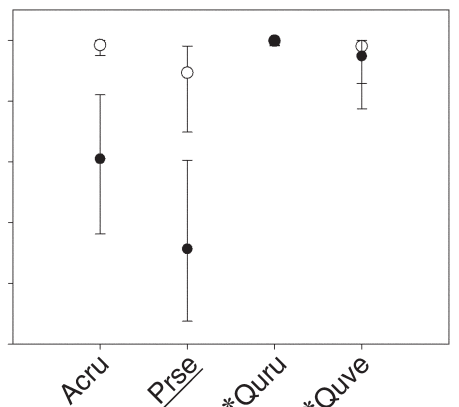

Soil: Robinia pseudoacacia south

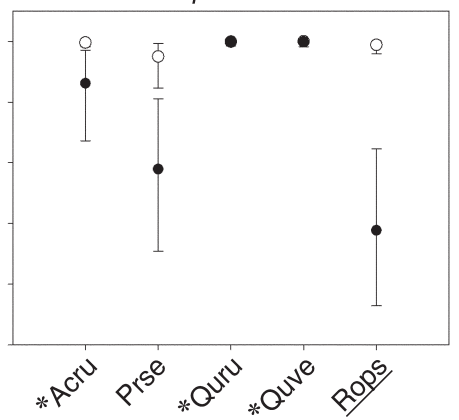

Species planted
Soil: Quercus rubra north

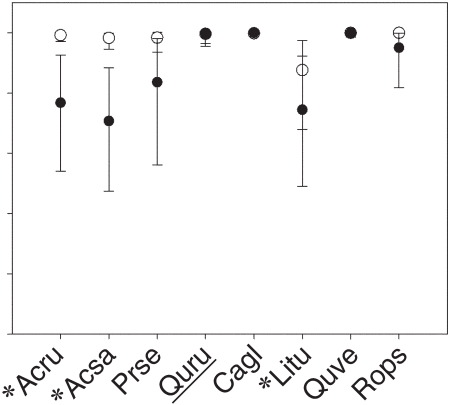

Soil: Quercus rubra south

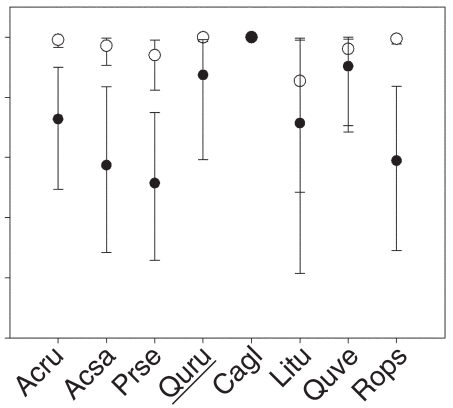

Species planted

FIG. 4. Predicted seedling survival (mean and 95\% PI) after 10 weeks in each soil source for each greenhouse study species based on model parameters from non-sterile soil. Conspecific seedling species codes are underlined. Asterisks indicate statistically different survival between heterospecific and conspecific seedlings in a given soil source based on nonoverlapping 95\% PI. For each species, the predicted intervals that do not overlap indicate statistically significant differences in survival between low and high light treatments. 
soils ( $P$. serotina seedlings), and northern A. rubrum and Q. rubra soils (R. pseudoacacia seedlings).

\section{DisCuSSION}

In this study, we investigated the role that plant-soil feedbacks (PSF) may play in determining tree range expansion in response to global warming. We found that field survival for most of the potential migrant tree species was similar or even higher than those of the local community. This finding suggests that these species may be able to establish in areas beyond their current distributional ranges. In the greenhouse experiment, we were able to assess the ubiquitous soil mediated interactions between tree adults and seedlings that may underlie patterns of survival. The majority of species grown in canopy-specific soils experienced strongly negative conspecific feedbacks mediated by soil biota. The effects of soil biota and plant-soil feedbacks on survival were restricted to low-light conditions for the majority of our study species (Figs. 3 and 4). For many species, soil biota in northern soils had less of an effect on survival, regardless of whether a species was local or migrant. Thus, southern populations of both local and migrant tree species may experience a release from soil biota effects during their migration northwards that may contribute to their successful establishment in new regions.

\section{The role of plant-soil feedbacks in tree range expansion}

Although other factors besides PSF (e.g., propagule availability) will also affect the success and rate of tree range expansion, our results provide additional support to previous work indicating that plant species may have better performance in an expanded range (e.g., Engelkes et al. 2008, van Grunsven et al. 2010, Callaway et al. 2011). This finding is similar to the often-reported results for exotic species invading a new area (Reinhart and Callaway 2006, Inderjit and van der Putten 2010). The greenhouse experiment allowed us to specifically evaluate the role of PSF in post-dispersal establishment potential of tree species into northern regions. For two out of four potential migrant species in the study ( $L$. tulipifera and $R$. pseudoacacia), we recorded higher survival in northern soils. Better survival in northern soils also occurred for A. rubrum, P. serotina, and $Q$. rubra (species whose range already extends throughout the region), as they were also released from what seems to be a more virulent pathogen community in the south. Range expansion may occur at a faster rate for $R$. pseudoacacia and the southern populations of $P$. serotina because of the relatively large release from negative PSF in northern heterospecific soils ( $>50 \%$; Fig. 3 b). For $Q$. rubra, even though survival is better in all tested northern soils than in the southern conspecific soil, the overall effect on survival is much smaller $(\sim 10 \%$; Fig. $3 b)$ and thus in relative terms may result in slower range expansion. Out of our study species, C. glabra, $Q$. velutina, and the southern populations of $A$. saccharum may all experience slower relative range expansion for different reasons. C. glabra may have slow range expansion because soil biota and PSF do not appear to influence survival in the seedling establishment phase. However, $Q$. velutina and southern populations of $A$. saccharum may have even slower or impeded range expansion due to PSF processes because seedling survival is lower in northern soils for these species.

\section{The role of plant-soil feedbacks on tree seedling establishment}

We were able to determine both the spatial ("homesouth" vs. "away-north") and specificity ("conspecific" vs. "heterospecific") effect of PSF by testing PSF for multiple species in each others' cultured soils. In our greenhouse study, PSF appear to be widespread and primarily driven by negative biota from soil near conspecific adult trees (Table 3), suggesting that dispersal away from conspecific adults is advantageous for most species. In addition, when comparing recruitment in soils collected under different tree species (the specificity of feedbacks), we found that in some soils ( $A$. saccharum, $P$. serotina, and $R$. pseudoacacia soils), conspecific seedlings were at a disadvantage relative to heterospecifics (Fig. 4). This result is likely due in some cases (e.g., P. serotina) to intrinsic differences in survival among species (e.g., statistically higher heterospecific survival relative to conspecific seedlings only occurred for large-seeded species). However, the higher survival by small-seeded heterospecific species in A. saccharum and $R$. pseudoacacia cultured soils indicate that these soil mediated feedbacks between tree adults and seedlings are somewhat species-specific. This result is similar to findings by Konno et al. (2011), in which a ubiquitous seedling pathogen can attack a wide range of host species, but virulence is stronger for conspecific than heterospecific individuals.

We were able to focus on both biotic and abiotic PSF because we took the unconventional approach of not trying to eliminate abiotic differences among soil sources (but see Bezemer et al. 2006). The majority of the negative conspecific feedbacks were due to soil biota, whereas the positive heterospecific feedbacks were primarily due to abiotic factors. We do not believe that the negative biotic feedbacks in our study were actually due to an increase in the concentration of nutrients in sterile soil (Powlsen and Jenkinson 1976) because we did not find any soil chemistry differences between sterile and non-sterile soils.

Heterospecific seedlings often survived best in $A$. saccharum soils, whereas $A$. saccharum seedlings had low survival in all soils (both their own and heterospecific soils; Appendix F: Fig. F1). The decline of A. saccharum in eastern North America is well-documented (Siccama et al. 2007) and thought to be due to a reduction in soil calcium status (Juice et al. 2006). However, our results suggest that the sensitivity of $A$. saccharum to soil source (the most negatively affected species by rank in five of 
six soils) may also contribute to its declining abundance, and there is evidence that $A$. saccharum seedlings are sensitive to mortality from a fungus in the genus Rhizoctonia (Cleavitt et al. 2011).

Lastly, we found $R$. pseudoacacia had reduced performance in conspecific soils taken from their expanded range (Figs. 3 and 4). Effects of conspecific soil on survival were due to abiotic factors, whereas effects of growth were due to soil biota (S. McCarthyNeumann and I. Ibáñez, unpublished data). These results suggest that for $R$. pseudoacacia, any release from enemies found in their native range and subsequent enhanced performance in their expanded and invaded ranges (e.g., Callaway et al. 2011) may be temporary and last only until $R$. pseudoacacia adults are present. Furthermore, heterospecific seedlings benefit from growing in soils cultured by $R$. pseudoacacia.

\section{Plant-soil feedbacks and the light environment}

Seedling survival is often thought to be higher in high light areas due to better carbon balance (Canham et al. 1999) and decreased disease (Augspurger 1990). However, our field results suggest that for many species, regardless of their shade tolerance, these sites may be hostile environments because they have lower levels of inorganic nitrogen (Appendix C) and higher levels of desiccation and possibly predation and herbivory.

The greenhouse experiment allowed us to explicitly investigate the complex interaction between light and the effect of PSF on seedling survival, as other factors such as soil moisture and nutrients and the lack of predation or herbivory remained the same. In general survival was higher at high light levels (Fig. 4). Results also indicate that PSF may be restricted to low light environments for most species and may provide an additional mechanism for explaining recruitment dynamics in temperate forests other than the classic shade-tolerance niche partitioning model (Kobe et al. 1995, Kobe 1999; Fig. 3). For instance, tree species classified as shade intolerant often have establishment restricted to high light areas. Reduced establishment in some species may not be due to physiological carbon balance requirements, but rather due to their susceptibility to soil pathogens in low light conditions. Consequentially, potential migrant species with strong negative conspecific feedbacks may be able to establish, at least in the short term, in shadier conditions in their expanded range, as they may be released from soil biota associated with conspecific adults.

The difference in seedling response to low light between the field (where survival was reduced in gap plots) and greenhouse experiments (where soil biota and plant-soil feedbacks were restricted to low light environments with corresponding reductions in survival) may be due to a variety of reasons. First, although the majority of species in the field had better survival in plots with lower light, the benefit derived from these canopy plots occurred for most species even when light and soil moisture were accounted for in the analysis. Thus, other factors associated with these habitats such as soil nutrient levels or herbivory and predation may have been more important than irradiance. Additionally, canopy plots experienced relatively moderate to high light levels $\left(\sim 13.9 \pm 3.7 \mu \mathrm{mol}\right.$ photons $\cdot \mathrm{m}^{2} \cdot \mathrm{s}$ PAR) relative to the low light treatment in the greenhouse $\left(\sim 0.5 \pm 0.2 \mu \mathrm{mol}\right.$ photons $\left.\cdot \mathrm{m}^{2} \cdot \mathrm{s} \mathrm{PAR}\right)$. Thus, seedlings in the field canopy plots may not have experienced low mortality due to soil biota and PSF because these effects were found to be restricted to lower light levels in the greenhouse.

\section{Conclusions}

The complementarities of the field and greenhouse experiments provided us with a comprehensive understanding of the role of plant-soil feedbacks (PSF) in seedling establishment and tree range expansion. The field experiment produced realistic establishment rates that we can use to compare species and inform vegetation models and management practices, while the greenhouse experiment allowed us to explore the mechanisms behind tree seedlings responses to PSF in the context of tree range expansion. This study reveals that migrant tree species can colonize and may even have better short-term survival as they migrate northwards due to a lack of conspecific adults (and the resulting negative PSF) in these northern communities. The current findings also suggest biotic mediated plantsoil feedbacks may enhance light gradient partitioning among tree species ultimately influencing succession and species coexistence in forest communities. Our results illustrate the complexity of the establishment process and the different environmental filters individuals experience (Harper 1977, Gurevitch et al. 2002), as well as give us a better understanding of the potential role of PSF in tree seedling establishment in response to climate change. The ultimate outcome for whether a seedling successfully establishes will depend on the complex interaction of all of those filters, and only by investigating and quantifying their effects will we be able to reliably predict shifts in species distributional ranges.

ACKNOWLEDGMENTS

We are grateful to two anonymous reviewers, Kurt Reinhart, and the PEDG and GCEL groups for helpful comments on the manuscript. We thank the numerous assistants who helped with field and greenhouse work. This research was funded by the National Science Foundation (DEB-EAGER 0947783) and the USDA McIntire-Stennis Program (USDA MICY000706).

\section{Literature Cited}

Agrios, G. N. 1997. Plant pathology. Fourth edition. Academic Press, San Diego, California, USA.

Andersen, P. K., O. Borgan, R. D. Gill, and N. Keiding. 1993. Statistical models based on counting processes. SpringerVerlag, New York, New York, USA.

Andersen, P. K., and R. D. Gill. 1982. Cox's regression model for counting processes: a large sample study. Annals of Statistics 10:1100-1120. 
Augspurger, C. K. 1990. Spatial patterns of damping-off disease during seedling recruitment in tropical forests. Pages 131-144 in J. Burdon and S. Leather, editors. Pests, pathogens, and plant communities. Blackwell Scientific, Oxford, UK.

Augspurger, C. K., and C. K. Kelly. 1984. Pathogen mortality of tropical seedlings: experimental studies of the effects of dispersal distances, seedling density, and light conditions. Oecologia 61:211-217.

Barnes, B. V., and W. H. Wagner. 2004. Michigan trees. University of Michigan Press, Ann Arbor, Michigan, USA.

Bever, J. D. 1994. Feedback between plants and their soil communities in an old field community. Ecology 75:19651977.

Bever, J. D., I. A. Dickie, E. Facelli, J. M. Facelli, J. N. Klironomos, M. Moora, M. C. Rillig, W. D. Stock, M. Tibbett, and M. Zobel. 2010. Rooting theories of plant community ecology in microbial interactions. Trends in Ecology and Evolution 25:468-478.

Bever, J. D., K. Westover, and J. Antonovics. 1997. Incorporating the soil community into plant population dynamics: the utility of the feedback approach. Journal of Ecology 85:561-573.

Bezemer, T. M., C. S. Lawson, K. Hedlund, A. R. Edwards, A. J. Brooks, J. M. Igual, S. R. Mortimer, and W. H. van der Putten. 2006. Plant species and functional group effects on abiotic and microbial soil properties and plant-soil feedback responses in two grasslands. Journal of Ecology 94:893-904.

Burns, R. M., and B. H. Honkala. 1990. Silvics of North America: 1. Conifers; 2, Hardwoods. Agriculture Handbook 654. USDA Forest Service, Washington, D.C., USA.

Callaway, R. M., E. J. Bedmar, K. Reinhart, C. G. Silvan, and J. N. Klironomos. 2011. Effects of soil biota from different ranges on Robinia invasion: acquiring mutualists and escaping pathogens. Ecology 92:1027-1035.

Canham, C. D., R. K. Kobe, E. F. Latty, and R. L. Chazdon. 1999. Interspecific and intraspecific variation in tree seedlings survival: effects of allocation to roots versus carbohydrates reserves. Oecologia 121:1-11.

Clark, J. S. 2005. Why environmental scientists are becoming Bayesians. Ecology Letters 8:2-14.

Cleavitt, N. L., T. J. Fahey, and J. J. Battles. 2011. Regeneration ecology of sugar maple (Acer saccharum): seedling survival in relation to nutrition, site factors, and damage by insects and pathogens. Canadian Journal of Forest Research 41:235-244.

Ehrenfeld, J. G., B. Ravit, and K. Elgersma. 2005. Feedbacks in the plant-soil system. Annual Review of Environment and Resources 30:75-115.

Engelkes, T., E. Morrie, K. J. F. Verhoeven, T. M. Bezemer, A. Biere, J. A. Harvey, L. M. McIntyre, W. L. M. Tamis, and W. H. van der Putten. 2008. Successful range-expanding plants experience less above-ground and below-ground enemy impact. Nature 456:946-948.

Finzi, A. C., C. D. Canham, and N. Van Breemen. 1998 a. Canopy tree soil interactions within temperate forests: species effects on $\mathrm{pH}$ and cations. Ecological Applications 8:447454.

Finzi, A. C., N. Van Breemen, and C. D. Canham. $1998 b$. Canopy tree soil interactions within temperate forests: species effects on soil carbon and nitrogen. Ecological Applications $8: 440-446$.

Fleming, T., and D. Harrington. 1991. Counting processes and survival analysis. Wiley, New York, New York, USA.

Gelman, A., and J. Hill. 2007. Data analysis using regression and multilevel/hierarchical models. Cambridge University Press, New York, New York, USA.

Gurevitch, J., S. M. Scheiner, and G. A. Fox. 2002. The ecology of plants. Sinauer Associates, Sunderland, Massachusetts, USA.
Harper, J. L. 1977. Population biology of plants. Academic Press, Waltham, Massachusetts, USA.

Ibáñez, I., J. S. Clark, and M. Dietze. 2008. Evaluating the sources of potential migrant species: implications under climate change. Ecological Applications 18:1664-1678.

Ibáñez, I., J. S. Clark, and M. Dietze. 2009. Estimating performance of potential migrant species. Global Change Biology 15:1173-1188.

Ibáñez, I., J. S. Clark, M. C. Dietze, K. Feeley, M. Hersh, S. LaDeau, A. McBride, N. E. Welch, and M. S. Wolosin. 2006. Predicting biodiversity change: outside the climate envelope, beyond the species-area curve. Ecology 87:1896-1906.

Inderjit, and W. H. van der Putten. 2010. Impacts of soil microbial communities on exotic plant invasions. Trends in Ecology and Evolution 26:512-519.

Juice, S. M., T. J. Fahey, T. G. Siccama, C. T. Driscoll, E. G. Denny, C. Eagar, N. L. Cleavitt, R. Minocha, and A. D. Richardson. 2006. Response of sugar maple to calcium addition to northern hardwood forest. Ecology 87:12671280 .

Kardol, P., N. J. Cornips, M. M. L. van Kempen, J. M. T. Bakx-Schotman, and W. H. van der Putten. 2007. Microbemediated plant-soil feedback causes historical contingency effects in plant community assembly. Ecological Monographs 77:147-162.

Klironomos, J. N. 2002. Feedback with soil biota contributes to plant rarity and invasiveness in communities. Nature 417:6770.

Kobe, R. K. 1999. Light gradient partitioning among tropical tree species through differential seedling mortality and growth. Ecology 80:187-201.

Kobe, R. K., S. W. Pacala, and J. A. Silander, Jr. 1995. Juvenile tree survivorship as a component of shade tolerance. Ecological Applications 5:517-532.

Konno, M., S. Iwamoto, and K. Seiwa. 2011. Specialization of a fungal pathogen on host tree species in a cross-inoculation experiment. Journal of Ecology 99:1394-1401.

Kulmatiski, A., J. Heavilin, and K. H. Beard. 2011. Testing predictions of a three-species plant-soil feedback model. Journal of Ecology 99:542-550.

Little, E. L., Jr. 1971. Atlas of United States trees. Volume 1, conifers and important hardwoods. U.S. Department of Agriculture Miscellaneous Publication 1146.

Mangan, S. A., S. A. Schnitzer, E. A. Herre, K. Mack, M. Valencia, E. Sanchez, and J. D. Bever. 2010. Negative plantsoil feedback predicts tree-species relative species abundance in a tropical forest. Nature 466:752-755.

McCarthy-Neumann, S., and R. K. Kobe. 2010a. Conspecific plant-soil feedbacks reduce survivorship and growth of tropical tree seedlings. Journal of Ecology 98:396-407.

McCarthy-Neumann, S., and R. K. Kobe. 2010b. Conspecific and heterospecific plant-soil feedbacks influence survivorship and growth of temperate tree seedlings. Journal of Ecology 98:408-418.

O'Hanlon-Manners, D. L., and P. M. Kotanen. 2004. Evidence that fungal pathogens inhibit recruitment of a shadeintolerant tree, white birch (Betula papyrifera), in understory habitats. Oecologia 140:650-653.

Parmesan, C., et al. 1999. Poleward shifts in geographical ranges of butterfly species associated with regional warming. Nature 399:579-583.

Powlsen, D. S., and D. S. Jenkinson. 1976. The effects of biocidal treatments on metabolism in soil-II. Gamma irradiation, air-drying and fumigation. Soil Biology and Biochemistry 8:179-188.

Prasad, A. M., L. R. Iverson, S. Matthews, and M. Peters. 2007. A climate change atlas for 134 forest tree species of the eastern United States. Northern Research Station, USDA Forest Service, Delaware, Ohio, USA. http://www.nrs.fs.fed. us/atlas/tree 
Reinhart, K. O., and R. M. Callaway. 2006. Tansley review. Soil biota and invasive plants. New Phytologist 170:445-457.

Reinhart, K. O., A. Packer, W. H. Van der Putten, and K. Clay. 2003. Plant-soil biota interactions and spatial distribution of black cherry in its native and invasive ranges. Ecology Letters 6:1046-1050.

Reinhart, K. O., A. A. Royo, W. H. Van der Putten, and K. Clay. 2005. Soil feedback and pathogen activity associated with Prunus serotina throughout its native range. Journal of Ecology 93:890-898.

Rillig, M., S. Wright, and V. T. Eviner. 2002. The role of arbuscular mycorrhizal fungi and glomalin in soil aggregration: comparing effects of five plant species. Plant and Soil 238:325-333.

Schnitzer, S. A., J. N. Klironomos, J. HilleRisLambers, L. L. Kinkel, P. B. Reich, K. Xiao, M. C. Rillig, B. A. Sikes, R. A. Callaway, S. A. Mangan, E. H. van Nes, and M. Scheffer. 2011. Soil microbes drive the classic plant diversityproductivity pattern. Ecology 92:296-303.

Siccama, T. G., T. J. Fahey, C. E. Johnson, T. W. Sherry, E. G. Denny, E. B. Girdler, G. E. Likens, and P. A. Schwarz. 2007. Population and biomass dynamics of trees in a northern hardwood forest at Hubbard Brook. Canadian Journal of Forest Research 37:737-749.
Spiegelhalter, D. J., N. Best, B. P. Carlin, and A. V. D. Linde. 2000. Bayesian measures of model complexity and fit. Journal of the Royal Statistical Society B 64:583-639.

Stinson, K. A., S. A. Campbell, J. R. Powell, B. E. Wolfe, R. M. Callaway, G. C. Thelen, S. G. Hallett, D. Prati, and J. N. Klironomos. 2006. Invasive plant suppresses the growth of native tree seedlings by disrupting belowground mutualisms. PLoS Biology 4(5):e140.

Sykorova, Z., K. Ineichen, A. Wiemken, and D. Redecker. 2007. The cultivation bias: different communities of arbuscular mycorrhizal fungi detected in roots from the field, from bait plants transplanted to the field, and from a greenhouse trap experiment. Mycorrhiza 18:1-14.

Thomas, A., B. O'Hara, U. Ligges, and S. Sturtz. 2006. Making BUGS open. RNews 6:12-17. http://cran.r-project.org/doc/ Rnews/

van Grunsven, R. H. A., W. H. van der Putten, T. M. Bezemer, F. Berendse, and E. M. Veenendaal. 2010. Plant-soil interactions in the expansion and native range of a poleward shifting plant species. Global Change Biology 16:380-385.

Walker, K. V., M. B. Davis, and S. Sugita. 2002. Climate change and shifts in potential tree species range limits in the Great Lakes region. Journal of Great Lakes Research 28:555-567.

\section{Supplemental Material}

\section{Appendix A}

Seed origins for field transplant and greenhouse experiments (Ecological Archives E093-245-A1).

\section{Appendix B}

Light and soil moisture measurements for field transplant and greenhouse experiments (Ecological Archives E093-245-A2).

\section{Appendix C}

Soil resource measurements for field transplant and greenhouse experiments (Ecological Archives E093-245-A3).

\section{Appendix D}

Greenhouse experimental design: soil sources each study species was grown in and number of seedlings allocated to these soil source treatments (Ecological Archives E093-245-A4).

\section{Appendix E}

Hazard curves over 10-week periods for field transplant and greenhouse species (Ecological Archives E093-245-A5).

\section{Appendix F}

Parameter estimates (mean posterior values and 95\% CI) for fixed-effects coefficients: $\beta$ parameters in the field transplant, and greenhouse studies (Ecological Archives E093-245-A6). 